\title{
The Effects of Inquiry-Based Learning Strategy on Chemistry Undergraduate Students' Conceptual Understanding and Science Process Skill Achievement in NMR Spectroscopy
}

\author{
Sutrisno, Rini Retnosari, Hayuni Retno Widarti \\ Department of Chemistry, Faculty of Mathematics and Natural Science \\ Universitas Negeri Malang \\ Malang, Indonesia \\ sutrisno.kimia@um.ac.id
}

\begin{abstract}
The purpose of this research was to investigate the effect of IBL strategy on chemistry undergraduate students' conceptual understanding and science process skill achievement in NMR Spectroscopy. This research involved two classes of Determination of Organic Structure course. One of them was chosen randomly as the control group while the other was selected as the experimental group. The experimental group was taught by the IBL strategy, whereas the control group was only taught by mean of the traditional lecture or Non-IBL strategy. Conceptual Understanding and Science Process Skill Tests were given to both groups as pre-test and post-test. The results presented that the IBL strategy has impact on chemistry undergraduate students' conceptual understanding and science process skill achievement. The evaluation results of the experimental group's conceptual understanding and science process skill test were better than those of the control group. The findings confirm that IBL strategy can enhance student's conceptual understanding and science process skill.
\end{abstract}

Keywords- inquiry-based learning strategy, conceptual understanding, science process skill, NMR spectroscopy

\section{INTRODUCTION}

Many literature reviews have reported the effectiveness of inquiry-based learning (IBL) strategy for science classes. According to the literature, inquiry-based learning actively involves students as scientists, facilitates them to develop their own knowledge based on their experiences, and justify their knowledge. In contrast, in traditional learning, students just follow the direction from their teacher to get their knowledge. The teacher is the main resource while the learners are uninvolved. Direct instruction is mainly used in traditional classes.

The shift from traditional learning to inquiry-based learning has improved the learning outcomes and student satisfaction [1]. Abdi [2], stated that students get higher scores when they obtain instructions through inquiry-based learning. The guided inquiry is more effective than the traditional method for teaching structure of matter [3]. Inquiry-based experiments, instead of traditional laboratories, make students more active [4]. Besides, inquiry-based learning can improve students' selfadvocacy and academic achievement [5].

Inquiry-based method was more effective in fostering students' acquisition of science process skills than the lecture method [6]. Gormally et al. [7], found significant improvement in science literacy skills and process skills when undergraduate students participated in an inquiry based laboratory experience for the entire semester. Inquiry-based teaching approach has positive influences on the pre-service science teachers' laboratory self-efficacy perceptions and scientific process skills [8]. Critical thinking, science process skills, creative, and science fair achievement of middle school students develop after inquiry-based learning had been implemented [9]. Improving critical thinking levels of the participants is resulted by students' active participation in lessons by taking part in activities and answering the questions asked by the researcher in and between group discussions. Improving students' critical thinking levels also improves their ability to make connections between claims and evidence [10]. In addition, inquiry-based learning can improve students' attitude, self-efficacy, and science reasoning abilities [11]

Students' motivation increased significantly after participating in inquiry-based learning. Students' self-efficacy increased as along with their perception on their ability in solving difficult problems. They also can integrate previous knowledge with new knowledge when they are involved actively in learning [12]. Inquiry-based approach also stimulates the intellectual curiosity of students. By giving students individual tasks, they will try to solve the problems independently. As a result of independent achievement, their self-confidence developed [13]. The students also enjoy learning by inquiry-based instruction and want to pursue their interests in science in the future [14]. Inquiry-based learning 
provides a solution for the biggest challenge in chemistry education, namely increasing the students' interest in chemistry [15]. Therefore, making inquiry-based learning widespread for science course will lead to the emergence of the healthier results for both teacher and researcher [4].

Implementing inquiry-based learning will enable students to be problem solvers. Students will develop their own knowledge of the abstract concepts either individually or in groups by using their thinking skills for the planning, execution, evaluation, reporting, and recording. They also formulate a hypothesis, gather materials, record and analyze data and draw conclusion on the lessons individually with less teacher interference [6]. When students are given opportunity to inquire and apply investigative behaviors during learning, they are more likely to develop analytical skills needed to reason and solve chemical problems. When they are actively engaged in the classroom to enable construction of new knowledge, it will lead them to develop self-confidence and hence self-learning [16]. These findings highlight the importance of incorporating inquiry-based learning in the undergraduate curriculum. Therefore, the purpose of this research was to investigate the effect of IBL strategy on chemistry undergraduate students' conceptual understanding and science process skill achievement in NMR Spectroscopy. The IBL strategy that was applied consists of six stages, i.e. orientation, investigation-exploration, discussioncommunication, conceptualization-conclusion, application, and reflection. These stages in IBL strategy modified the results from the IBL in literature.

\section{MethodOLOGY}

\section{A. Research Design}

The study used quantitative methods in collecting research data with quasi-experimental research design. This study involved two classes of the course of Organic Structure Determination in the topic of NMR Spectroscopy $\left({ }^{1} \mathrm{H}\right.$ - and ${ }^{13} \mathrm{C}$ NMR spectroscopy). One class acted as the experimental class or group (28 students), and the other class as a control class or group (26 students). Each class consisted of participants of third year undergraduate students who have been studying in the Department of Chemistry of Universitas Negeri Malang. These classes were started at the beginning of the semester by the school administration, so it was not possible to assign students randomly to both experimental and control groups. Each participant in the control group was chosen randomly while the others were in the experimental group. The experimental group was taught by the IBL strategy whereas the control group only learned through the traditional lecture so called as the Non-IBL strategy.

\section{B. Instrument and Data Collection}

In determining the effectiveness of IBL strategy in enhancing students' conceptual understanding and science process skill, the instrument development was used for the topic of NMR spectroscopy. The instrument contains 50 questions focusing on the students' concepts of organic structure determination based-on NMR spectroscopy and a 10- question focusing on their science process skill such as identifying and defining variables, formulating hypothesis, collecting and transforming data, interpreting data, and drawing conclusion and generalization. The instruments were given to both groups in pre-test and post-test in order to measure any changes in the students' abilities. The content validity of this study was examined by one chemistry lecturer and one chemical education lecturer. The data were analyzed to calculate the means, standard deviations, and N-Gain value.

\section{Description of IBL Strategy Intervention}

The research design included six stages (i.e. orientation, investigation-exploration, discussion-communication, conceptualization-conclusion, application, and reflection) as described below:

\section{1) Stage 1: Orientation}

The learning organization in this stage was conducted classically. The orientation stage included:

- Preparing students for learning about the NMR Spectroscopy by providing motivation, creating interest, generating curiosity, and making connections to prior knowledge (i.e. radiation of electromagnetic wave and magnetic field equation, and $\mathrm{C}$-atomic hybridization).

- Identifying learning objectives and criteria for success. As a result, the students understand about what is being learned and feel that the topic is important and useful so that the learning is meaningful for students.

- Providing vocabulary terms, prerequisites, and references as learning resources for students to begin learning something new.

- Proposing the questions, problems, and/or hypothesis. For example, the reason why NMR-Spectroscopy can be used to identify or determine the organic structure.

\section{2) Stage 2: Investigation - Exploration}

The learning organization in Stage 2 was conducted by individual-small group-classical. The activities give students a plan or a set of tasks to follow that embody the points to be learned and that lead to meeting the learning objectives. In this stage, students have the opportunity to make observations, collect, examine, and analyze data or information, investigate relationships, propose question, and test hypotheses.

- To read, discuss, and explored by table, data, expository of basic principle about NMR Spectrophotometer;

- To collect data and information on NMR-spectroscopy characteristic and analyze the data that has been collected. The data include nuclear resonance frequency and chemical shift $(\delta, \mathrm{ppm})$, types of $\mathrm{H}$ and $\mathrm{C}$-atomics, i.e. $\mathrm{sp}^{3}$ alkanes $\left(\mathrm{CH}^{3}, \mathrm{CH}^{2}\right.$, and $\left.\mathrm{CH}\right), \mathrm{sp}^{2}$ (alkanes, aromatic, aldehydic), and $\mathrm{sp}(\mathrm{CH} \equiv$ and $\mathrm{C} \equiv \mathrm{N})$; signals on NMR spectrum;

- To describe and discuss about the routine analysis by NMR-Spectroscopy (integration, coupled-decoupled \& coupling constant, ORD/SFORD, and DEPT, as well as its effects on the performance of the NMR spectra); 
- To interpret the data including analysis and synthesis to create students' new knowledge. The collection of chemical shift $(\delta, \mathrm{ppm})$ on NMR-spectrum gives identities and possible structure connected by other spectra (i.e. mass, UV, and IR spectra).

\section{3) Stage 3: Discussion - Communication}

Learning organization in Stage 3 was conducted by individual-small group-classical approach. The stage included:

- To communicate the findings obtained in Stage 2 (investigation-exploration) including:

a. The frequency of nuclear resonance $(\mathrm{H}$ and $\mathrm{C})$ and chemical shifts, types of $\mathrm{H}$ and/or $\mathrm{C}$ atom: $\mathrm{sp}^{3}$ alkanes $\left(\mathrm{CH}_{3}, \mathrm{CH}_{2}\right.$, and $\left.\mathrm{CH}\right), \mathrm{sp}^{2}$ (alkene, aromatics, aldehydics), and $\mathrm{sp}(\mathrm{CH} \equiv$ and $\mathrm{C} \equiv \mathrm{N})$, as well as signals of ${ }^{1} \mathrm{H} \&{ }^{13} \mathrm{C}$-NMR spectra.

b. A routine analysis method by NMR spectrophotometer: integration, coupled-decoupled, ORD/SFORD, DEPT, and effects' performance of NMR spectra. The communication activity is in the form of a presentation of the investigation-exploration results and collecting feedback from other students and/or lecturer in the classroom, and discussions of such feedback in the classroom.

c. To classically discuss or explain the findings and analysis that are presented.

d. Identifying the discussion results that will be the students" "self-conception".

\section{4) Stage 4: Conceptualization - Conclusion}

Learning organization in Stage 4 was conducted by individual-small group-classical approach. The concepts are invented, introduced, or formed by the students as a result of the exploration. Teachers engage students to discover and develop their conceptual understanding. The introduced questions make the students think critically and analytically. These questions are called guided-inquiry, critical thinking, or key questions and they aimed to guide the learner in the exploration. The questions include:

How a chemical shift and mode of NMR spectra can be identified or support the organic structure judgment?

These questions are used to direct and lead the students to make appropriate connections and conclusions, and help them to construct an understanding of the concept being learned. The stage is described below:

- To form a concept or the pattern of the main scientific results of the investigation assisted by lecturers who provides questions to "force" the students to think critically and analytically. These questions are in the form of guided-inquiry that train critical thinking, or key or principle questions that guide exploration, such as: How can chemical shift values and the NMR spectrum patterns identify or help determining the molecular structure.
- Assigning tasks, directing the received information, more practice of NMR spectra analysis and connecting it with the main chromophore of organic compound.

- To draw appropriate conclusions, and construct (understand) the concept of NMR spectra as a determinant of organic molecular structure. The value of chemical shift, area of integration, and signal splitting effect of coupling to determine the type and group of nuclear ( $\mathrm{C}$ and/or $\mathrm{H}$ ) and their relationship to the completely molecular organic structure.

- To draw a conclusion (whole-comprehension) of what has been explored and interpreted as a new concept or knowledge for them. In this case the chemical shift $(\delta$, $\mathrm{ppm})$, the carbon group, i.e., carbon-sp ${ }^{3}$ alkanes $\left(\mathrm{CH}_{3}\right.$, $\mathrm{CH}_{2}$, and $\mathrm{CH}$ ), carbon-sp ${ }^{2}$ (alkene, aromatic, aldehyde), and carbon-sp $(\mathrm{CH} \equiv$ and $\mathrm{C} \equiv \mathrm{N})$. The signals in the ${ }^{1} \mathrm{H}$ and 13C-NMR spectra and its pattern to form or build the organic structure completely and correct (in accordingly with its physical and chemical properties).

\section{5) Stage 5: Application}

Learning organization in the application stage was conducted by individual-small group-classical approach. Application is needed to reinforce and extend students' concepts. They can use their new knowledge to solve exercises, problems, and new research situations. The students' confidence in simple situations and familiar contexts will be built after solving the exercises. When students solve other problems, they can transfer the new knowledge to unfamiliar contexts, synthesize it with other knowledge, and use it in new and different ways to solve real-world problems. Research questions identify opportunities for learners to extend learning by raising new issues, questions, or hypotheses. Activities undertaken at this stage are:

- Practices in applying the concept/knowledge of chemical shifts $(\delta, \mathrm{ppm})$, groups or types of carbon, i.e. carbon-sp ${ }^{3}$ alkane $\left(\mathrm{CH}_{3}, \mathrm{CH}_{2}\right.$, and $\left.\mathrm{CH}\right)$, carbon-sp ${ }^{2}$ (alkene, aromatics, aldehydic), and carbon sp ( $\mathrm{CH} \equiv$ and $\mathrm{C} \equiv \mathrm{N}$ ), and the signals on the ${ }^{1} \mathrm{H}$ - and ${ }^{13} \mathrm{C}-\mathrm{NMR}$ spectrum and its pattern to solve problems in the same context but in different situations.

- Analysis on the peaks (main signals and splitting signals) characteristic of a ${ }^{1} \mathrm{H}$ - and ${ }^{13} \mathrm{C}-\mathrm{NMR}$ spectrum (known $\delta$-) and interpreting them to construct the identity of the organic compound structure.

- Deepening, sharpening, and widening the concepts that have been obtained through exercises (solving problems in the form of individual and/or small groups).

\section{6) Stage 6: Reflection}

Learning organization in reflection stage was conducted by individual and classical approach. This activity involves validating and reflecting the concepts that the students have learned, and assessing their performance. In the validation stage, students can report their results to their peers and they will get feedbacks regarding the content and the quality of their reports from their teacher. The aim of reflecting process is giving reward to students for their hard work. Beside that their 
knowledge is also consolidated. Self-assessment process is important to be done because students will recognize what they have done well, what they need to improve, and what strategies they need to develop in order to achieve these improvements. They are both encouraged and motivated to work toward their goals. Self-assessment is the key to success in courses, college, and careers because it produces continuous improvement. There are two main activities at this stage:

- The learning activities end with validation of the results achieved by the students, what reflections have been learned, and assess their performance. Validation and reflection is done by:

a. Exploring or collecting data and information on characteristics of $1 \mathrm{H}$ - and 13C-NMR spectroscopic, and analyzing the data and information that have been obtained. The data in question are: resonance frequency of carbon nuclear and chemical shift $(\delta$, $\mathrm{ppm}$ ), groups or types of carbon, i.e. carbon-sp3 alkane $\left(\mathrm{CH}_{3}, \mathrm{CH}_{2}\right.$, and $\left.\mathrm{CH}\right)$, carbon-sp ${ }^{2}$ (alkenes, aromatic, aldehydic), and carbon $\mathrm{sp}(\mathrm{CH} \equiv$ and $\mathrm{C} \equiv \mathrm{N})$; The signals on the ${ }^{1} \mathrm{H}$ - and ${ }^{13} \mathrm{C}$-NMR spectra; Methods and techniques of the routine NMR spectrophotometric analysis: coupled-decoupled, ORD / SFORD, and DEPT, and their effect on the performance of the NMR spectra.

b. Making conclusions (in group and/or individually) about NMR-spectroscopic data and communicate it to their peers in the classroom (other students and lecturers) to obtain feedback on the content and quality of the conclusions.

c. Rewarding his hard work.

- Self-assessment. It is the key to improve performance. Students deliver what they could do best, what they need to improve, and what strategies they need to develop in order to achieve improvement. It is expected for the students to be motivated and to develop themselves in order to achieve a competence;

- Reflection, which describes, criticizes, evaluates, and discusses the whole NMR Spectroscopy study or its specific stages. Students make reflection through internal discussion in group or with the whole class.

\section{RESULT AND DISCUSSION}

Table 1 indicates that the conceptual understanding of the experimental group is better than that of the control group as shown by the mean values, standard deviation, and N-Gain values. Besides, the science process skill of the experimental group is also better than that of the control group as presented in Table 2.
TABLE I. THE HIGHEST AND LOWEST SCORE, MEAN VALUES, STANDARD DEVIATION AND N-GAIN OF THE EXPERIMENTAL AND CONTROL GROUPS FOR PRETESTS AND POSTTEST IN TERM OF CONCEPTUAL UNDERSTANDING

\begin{tabular}{|c|l|l|l|l|l|l|}
\hline Variable & Group & $\begin{array}{c}\text { The } \\
\text { Highest } \\
\text { Score }\end{array}$ & $\begin{array}{c}\text { The } \\
\text { Lowest } \\
\text { Score }\end{array}$ & Mean & $\begin{array}{c}\text { Standard } \\
\text { Deviation }\end{array}$ & $\begin{array}{c}\text { N- } \\
\text { Gain } \\
(\%)\end{array}$ \\
\hline \multirow{2}{*}{ Pre-test } & Experimental & 47 & 13 & 30.75 & 8.97 & - \\
\cline { 2 - 7 } & Control & 67 & 13 & 24.78 & 12.55 & - \\
\hline \multirow{2}{*}{ Post-test } & Experimental & 93 & 33 & 63.15 & 14.04 & 46.79 \\
\cline { 2 - 7 } & Control & 77 & 36 & 51.54 & 9.22 & 35.58 \\
\hline
\end{tabular}

TABLE II. MEAN VALUES, STANDARD DEVIATION, AND N-GAIN VALUES OF THE EXPERIMENTAL AND CONTROL GROUPS FOR PRE-TEST AND POST-TEST SCORES REGARDING SCIENCE PROCESS SKILL

\begin{tabular}{|c|l|l|l|l|}
\hline Variable & \multicolumn{1}{|c|}{ Group } & Means & Standard Deviations & $\begin{array}{c}\text { N-Gain } \\
(\mathbf{\%})\end{array}$ \\
\hline \multirow{2}{*}{ Pre-test } & Experimental & 19.16 & 9.71 & - \\
\cline { 2 - 5 } & Control & 17.44 & 8.86 & - \\
\hline \multirow{2}{*}{ Post-test } & Experimental & 50.37 & 17.74 & 38.61 \\
\cline { 2 - 5 } & Control & 40.33 & 13.67 & 27.73 \\
\hline
\end{tabular}

The results point out that IBL strategy has an impact on the undergraduate students' conceptual understanding and science process skill. IBL strategy is better than traditional teaching to be used as the instructional learning for higher education level. Therefore, IBL is one of the innovative strategies that can be effectively implemented in the course of Organic Structure Determination especially for the NMR spectroscopy topic. Such result is in good agreement with [17], they stated that inquiry-based instruction for IR spectroscopy learning is better than the traditional teaching. Also, the implementation of IBL strategy for various topics or subjects is needed in order to create a different learning atmosphere in higher education level. Nevertheless, teachers should prepare a learning design via IBL strategy so that the students can be more actively involved in their learning. The time required for the implementation of the IBL strategy is longer than that of the traditional method. Therefore, the teacher should be able to effectively organize the time.

\section{CONCLUSION}

According to the results of this study, the conceptual understanding and science process skill of chemistry undergraduate students were increased after the implementation of the IBL strategy on the topic of NMR spectroscopy. Therefore, IBL is an innovative strategy that is effective for Organic Structure Determination Course especially on the NMR spectroscopy topic. In addition, the implementation of IBL strategy on various topics is necessary for determining organic structure.

\section{ACKNOWLEDGEMENTS}

We thank the Ministry of Research, Technology, and Higher Education of the Republic of Indonesia for the research grant. This work was supported the 4 in 1 project of the Islamic Development Bank in Universitas Negeri Malang. 


\section{REFERENCES}

[1] M. Smallhorn, J. Young, N. Hunter, and K. B. da Silva, "Inquiry-based learning to improve student engagement in a large first year topic," Student Success, vol. 6, no. 2, 2015.

[2] A. Abdi, "The effect of inquiry-based learning method on students' academic achievement in science course," Univers. J. Educ. Res., vol. 2, no. 1 , pp. 37-41, 2014.

[3] M. Vlassi and A. Karaliota, "The comparison between guided inquiry and traditional teaching method. A case study for the teaching of the structure of matter to 8th grade Greek students," Procedia-Social Behav. Sci., vol. 93, pp. 494-497, 2013.

[4] Z. Bayram, Ö. Ö. Oskay, E. Erdem, S. D. Özgür, and Ş. Şen, "Effect of inquiry based learning method on students' motivation," ProcediaSocial Behav. Sci., vol. 106, pp. 988-996, 2013.

[5] A. Kuklok, "The effects of inquiry based practices on students problem solving competence," St. Catherine University, St. Paul, Minnesota, 2016.

[6] Ghumdia and A. Adams, "Effects of inquiry-based teaching strategy on students' science process skills acquisition in some selected biology concepts in secondary schools in Borno State," Int. J. Sci. Res., vol. 1, no. 2, pp. 96-106, 2016.

[7] C. Gormally, P. Brickman, B. Hallar, and N. Armstrong, "Effects of inquiry-based learning on students' science literacy skills and confidence," Int. J. Scholarsh. Teach. Learn., vol. 3, no. 2, 2009.

[8] Ş. E. N. Ceylan and G. S. VEKLI, "The Impact of Inquiry Based Instruction on Science Process Skills and Self-efficacy Perceptions of Pre-service Science Teachers at a University Level Biology Laboratory," Univers. J. Educ. Res., vol. 4, no. 3, pp. 603-612, 2016.
[9] C. M. Longo, "Effects of an inquiry-based science program on critical thinking, science process skills, creativy, and science fair achievement of middle school students," Western Connecticut State University, 2012.

[10] M. Duran and İ. Dökme, "The effect of the inquiry-based learning approach on student's critical-thinking skills," Eurasia J. Math. Sci. Technol. Educ., vol. 12, no. 12, pp. 2887 - 2908, 2016.

[11] N. O. Roster, "The effects of inquiry-based teaching on attitudes, selfefficacy, and science reasoning abilities of students in introductory biology courses at a rural, open-enrollment community college," Oklahoma State University, 2006.

[12] H. L. Tuan, C. C. Chin, C. C. Tsai, and S. F. Cheng, "Investigating the effectiveness of inquiry instruction on the motivation of different learning styles students," Int. J. Sci. Math. Educ., vol. 3, no. 4, pp. 541566, 2005.

[13] L. A. Pilcher, D. L. Riley, K. C. Mathabathe, and M. Potgieter, "An inquiry-based practical curriculum for organic chemistry as preparation for industry and postgraduate research," South African J. Chem., vol. 68 , pp. 236-244, 2015.

[14] J. Yorke-Servis, "A comparison study on teacher-centered and inquirybased instruction in science education of middle school students with learning disabilities: what is effective?," Rowan University, 2012.

[15] M. Aksela and M. Boström, "Supporting students' interest through inquiry-based learning in the context of fuel cells," Mevlana Int. J. Educ., vol. 2, no. 3, pp. 53-61, 2012.

[16] A. R. Al Zarooni and B. Esmaeil, "Impact of Guided Inquiry on Tenth Graders' Understanding of Chemical Bonds," United Arab Emirates University, 2014.

[17] J. Bennett and T. Forster, "IR cards: inquiry-based introduction to infrared spectroscopy," J. Chem. Educ., vol. 87, no. 1, pp. 73-77, 2009. 